Max-Planck-Institut für demografische Forschung

Max Planck Institute for Demographic Research

Konrad-Zuse-Strasse 1 - D-18057 Rostock · GERMANY

Tel +49 (0) 3812081 - 0; Fax +49 (0) 3812081 - 202;

http://www.demogr.mpg.de

MPIDR WORKING PAPER WP 2007-017

APRIL 2007

\title{
Transition of nuptiality and fertility onset in the Czech Republic since the 1990 s - the role of women's education and its expansion
}

Kryštof Zeman (zeman@ demogr.mpg.de)

This working paper has been approved for release by: Hill Kulu (kulu@ demogr.mpg.de)

Deputy Head of the Laboratory of Contemporary European Fertility and Family Dynamics.

(C) Copyright is held by the authors.

Working papers of the Max Planck Institute for Demographic Research receive only limited review. Views or opinions expressed in working papers are attributable to the authors and do not necessarily reflect those of the Institute. 


\title{
TrANSITION OF NUPTIALITY AND FERTILITY ONSET \\ IN THE CZECH REPUBLIC SINCE THE 1990S - \\ THE ROLE OF WOMEN's EDUCATION AND ITS EXPANSION
}

\author{
Kryštof Zeman \\ Czech Statistical Office \\ Demographic Statistics Section \\ Na padesátém 81, 10082 Praha 10 \\ Czech Republic \\ krystof.zeman@czso.cz
}

\begin{abstract}
In this article we argue that social and economic changes in the past fifteen years have influenced distinct socio-economic categories of women differently. We show that the transition of family formation behaviours was not uniform but rather dependent on the educational level of women. We found wide differences between educational categories in terms of the changes in level, timing and sequencing of first birth and first marriage, using the techniques of nuptiality and fertility life tables and the hazard modelling of first marriage and first conception. Two different types of "trendsetters" were identified in Czech society. The trendsetters of non-marital fertility are women with primary education, who tend to be lone mothers or to cohabit even after childbirth. The second group of trendsetters are more highly educated women, who postpone their fertility onset until their 30s, but who still place their first childbirth traditionally inside marriage. The number of possible reasons for the family formation transition is manifold, ranging from the changing economic roles of women through actual setting of family policy to the post-modern value change, all further reinforced by educational expansion since the 1990s. There is no general explanation of the transitional behaviour, as women of different education levels are reacting differently to the social and economic changes.
\end{abstract}




\section{INTRODUCTION}

Since the 1990s the fertility and nuptiality behaviour of Czech women has changed substantially. Both the sharp decline in fertility and nuptiality levels and the postponement of childbirth until higher ages have been extensively analysed by many authors. Explanations for these changes that have been proposed and discussed range from economic constraints (Stloukal, 1997, Rychtaříková, 2000) to the notion of the second demographic transition and the change in values and attitudes of individuals (Fialová and Kučera, 1997, Rabušic, 2001, Sobotka et al., 2003). A deeper examination of the motivation of individual behaviours reveals that women of different socio-economic status reacted somewhat differently with respect to their demographic behaviours. Since educational attainment is an important socioeconomic determinant (or proxy) of fertility and since data about this determinant is readily available (Rychtaříková, 2004, Hamplová and Řeháková, 2006), we pose the questions: What is the role of women's education in the change in level, timing and sequencing of family formation events ${ }^{1}$ that has been observed since the $1990 \mathrm{~s}$, and how is it related to the educational transition in the Czech Republic? We use individual data on births and marriages from 1991-2005 linked according to the unique ID number of the women, and Census data from 1991 and 2001. Our analysis employs the techniques of fertility and nuptiality tables and the hazard modelling of first birth conception and first marriage.

The paper is structured as follows. After the review of theoretical considerations on the impact of education on family formation we will introduce the situation in the Czech Republic, focusing on the educational expansion and the explanation of obstacles to combining family duties with economic roles for women at distinct educational levels; we will also review the previous findings dealing with the topic. Then we explain the research design and define the techniques of analysis and modelling. Finally, we will present our findings, summarize the analysis, and draw some important conclusions.

\section{THEORY - THE IMPACT OF EDUCATIONAL ATTAINMENT ON FAMILY FORMATION}

The negative relationship between women's education and family formation is one of the most consistently reported findings in the literature (e.g. Blossfeld and Huinink, 1991, Hoem, 1986, Kravdal, 2004, Kreyenfeld, 2000, Liefbroer and Corijn, 1999, Marini, 1984, Rindfuss et al., 1980, 1996). The relationship between educational enrolment and attainment on one

\footnotetext{
${ }^{1}$ In this paper the term 'family formation' is used to mean conception of first child, first childbirth and first marriage, even if the first order is not always explicitly stated.
} 
side and entering into marriage and parenthood on the other is dependent on several conditions: in particular, it depends on the level of incompatibility of education, work and family and on the division of gender roles in society. Liefbroer and Corijn (1999) recognise two dimensions of incompatibility of education and labour and family formation: the cultural dimension is related to values and norms concerning the role of women in society, and the structural dimension refers to actual social opportunities and constraints on the roles of women. In societies with a higher incompatibility of the women's roles, the negative effect of education on family formation is expected to be stronger.

\subsection{Education and first childbirth}

There are several reasons why women with higher education postpone childbearing to later ages. First, because schooling is generally incompatible with childbearing in most societies, there is the direct effect of educational enrolment, which is longer for those in higher education (Blossfeld and Huinink, 1991). In fact, this effect intensified recently as more women entered higher education and the enrolment period for distinct levels of education lengthened (Rindfuss et al., 1996). Second, after finishing schooling women with higher education tend to get better jobs, which means that the opportunity costs to them of having children become higher (Gustafsson, 2001) and there is a fear that early withdrawal from the labour market could result in "status loss" (Kreyenfeld, 2000). This effect tends to diminish or disappear at older ages, suggesting that women with higher education postpone family formation rather than reduce it (Liefbroer and Corijn, 1999, Blossfeld and Jaeninchen, 1992).

Concerning the direction of causality between educational level and timing of birth, the reciprocal relationship was found to be dominated by the effect from education to age at first birth (Rindfuss et al., 1980). However, there is also still the indirect effect of withdrawing from the educational career due to unwanted/unplanned pregnancy at young ages (Marini, 1984).

\subsection{Education and entering marriage}

The close link between marriage and first birth has weakened in recent decades due to the contraceptive revolution that led to increasing control over one's own reproduction and also due to the spread of cohabitation, both as a premarital phase and an alternative to marriage. The impact of educational attainment on family formation has recently become much stronger with regard to parenthood than with regard to marriage (Liefbroer and Corijn, 1999), since the responsibilities of marriage interfere to a lesser extent with educational enrolment 
than those of motherhood (Marini, 1984). However, higher educated women tend to postpone marriage until later ages (Hoem, 1986), and an early marriage can also induce a woman to drop out of education (Billari and Philipov, 2003).

According to Oppenheimer (2003), the spouses with less attractive matches (in economic terms) postpone the marriage in favour of staying in unwed partnerships. Since poorly educated women tend to have relationships with poorly educated men (Srb, 2006), these matches are less favourable and have a lower propensity to end in marriage; a larger proportion tends to live long-term in cohabitation than is to be found among the higher educated.

In the past few decades, cohabitation has become increasingly popular in Western societies and it can now even be considered to be an important part of the family formation process. Interestingly, cohabitation was initiated by different social classes in different countries: in France, Great Britain or Netherlands cohabitation started as a living arrangement of higher educated women or even as a campus movement, whereas in Norway, Sweden, USA or even in Eastern Germany it emerged rather as a living arrangement among lower educated and working class women (Liefbroer and Corijn, 1999, Hoem, 1986, Konietzka and Kreyenfeld, 2001). As we will show in the next chapter, the latter is also the case in the Czech Republic.

\section{CZech Republic - BACKground}

Since the collapse of the communist regime in 1989, the Czech Republic has been passing through an intense economic and societal transition. The fast development triggered profound changes in demographic behaviour, which were especially intense in the first half of the 1990s. The decline in fertility and nuptiality rates and the postponement of family formation until higher ages has been analysed extensively by many authors (e.g. Fialová and Kučera, 1997, Rychtaříková, 2000, Pavlík and Kučera, 2001, Rabušic, 2001, Sobotka et al., 2003, Zeman, 2006), so in this paper we will reduce this introduction to the presentation of figures in Table 1. The demographic changes are clear: Czech society has been facing a rapid transformation of fertility and nuptiality behaviour accompanied by the weakening of the coupling of the two processes, a spread of cohabitation, an increase in non-marital childbearing, a decrease in the proportion of "shotgun" marriages, the substitution of abortion by modern contraception, and persistently high divorce rates. 
Table 1: Background characteristics of recent demographic developments in the Czech Republic

\begin{tabular}{|l|r|r|r|r|}
\hline & 1990 & 1995 & \multicolumn{1}{|c|}{2000} & 2005 \\
\hline Total fertility rate & 1.89 & 1.28 & 1.14 & 1.28 \\
Mean age at first childbirth & 22.5 & 23.3 & 24.9 & 26.6 \\
Premarital conceptions of $1^{\text {st }}$ marital births (\%) & 54 & 51 & 42 & 32 \\
Non-marital births (\%) & 8.6 & 15.6 & 21.8 & 31.7 \\
\hline Total female first marriage rate & 0.96 & 0.80 & 0.74 & 0.69 \\
Mean age at first marriage (female) & 21.4 & 24.6 & 26.4 & 28.1 \\
Total divorce rate (\%) & 38 & 38 & 41 & 47 \\
\hline Total abortion rate & 1.8 & 0.8 & 0.6 & 0.5 \\
Hormonal contraception usage (15-49 years, \%) & 4 & 19 & 32 & 45 \\
\hline
\end{tabular}

Source: Czech Statistical Office

\subsection{Sequencing of conception, childbirth and marriage - premarital conceptions and}

\section{non-marital childbearing, cohabitation and lone motherhood}

The first marriage in the Czech Republic traditionally interplayed with childbearing; in the late 1980s and early 1990s, the proportion of first children who were conceived before marriage but delivered inside marriage exceeded $50 \%$ and so about six out of ten firstmarrying brides got married while pregnant. A total of more than $80 \%$ of the children were delivered within 2 years of marriage. The proportion of non-marital births was small, not exceeding $10 \%$, but among the primary educated the proportion reached a third, even at that time. During the later 1990s the strong link between marriage and childbearing weakened: the proportion of non-marital births increased significantly, the pressure to marry in case of pregnancy was relaxed, and the utilisation of premarital and non-marital cohabitation and other types of informal ties was spreading (Zeman, 2003).

Figure 1 describes the changes in sequencing of conception and birth of first child and of first marriage, using an explanation based on three types of behaviour: "traditional" behaviour, when the conception of child is timed after marriage; the "shotgun" marriages typical of the socialist era; and the recently emerging phenomenon of childbearing outside marriage. The results are striking: the proportion of those who conceive the first child after marriage has not changed dramatically in any educational category, however the variability across the categories is wide - during the 1990-2005 period the proportion of those who behave "traditionally" oscillated around 35\% among those with secondary education but without graduation, around 50\% among those with "maturita", and around 65-70\% among university graduates. It is only among primary educated women where the traditional mode of family formation has decreased in popularity. Striking changes, however, can be observed in the behaviour of single pregnant women: other than in the past, when pregnancy was a strong impetus to marry promptly before birth delivery, women now tend to stay single, either in cohabitation or as lone mothers. Overall there was an increase in the proportion of 
non-marital first births from $12 \%$ in 1991 to $40 \%$ in 2005, but both the pattern of the increase and the actual values vary significantly across the different educational groups: there was a steady progress to $19 \%$ among the university educated, but a sharp increase to $80 \%$ among the primary educated.

\section{Figure 1. Family-formation types according to the sequencing of conception and birth of first child and} marriage by educational level of mother
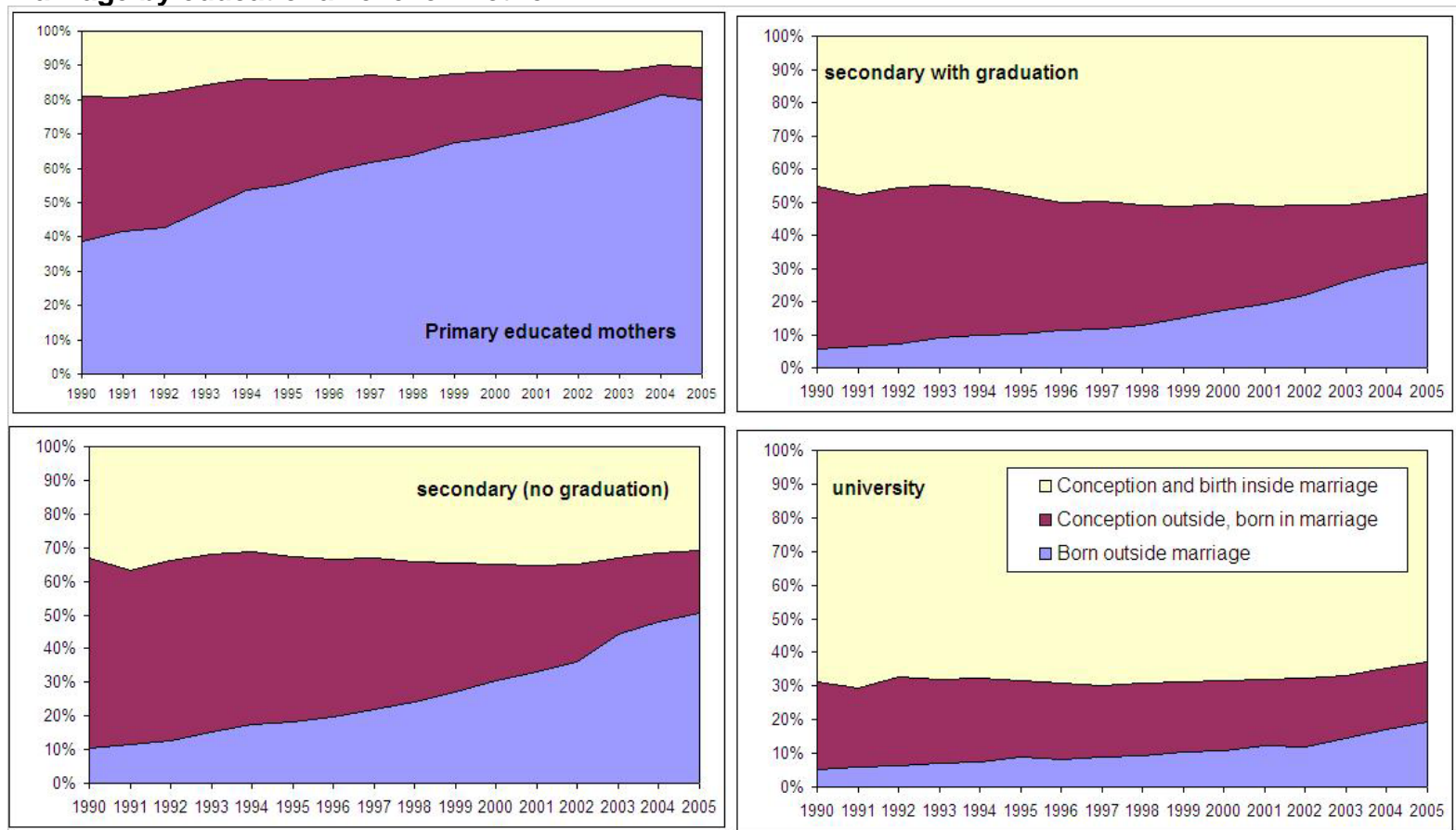

Source: Own calculations based on data from the Czech Statistical Office

Cohabitation is seen as being equal to marriage in many aspects in the Czech society; however there is still high level of esteem for the institution of marriage (Sobotka et al., 2003). Cohabitation in the Czech Republic was already present as a living arrangement for divorced or widowed partners in the first half of the twentieth century, and since the 1980s it has also been spreading in popularity as a premarital phase of partnership, initially among lower-educated young people (Možný, 1987; Rychtaříková, 1994). Hamplová (2003) shows that better-educated women were still less inclined towards cohabitation than in the 1990s.

There has not been any systematic research conducted on cohabitations in the Czech Republic so far and the figures from the population census are seriously misreported ${ }^{2}$. According to the Family and Fertility Survey conducted in 1997, the share of cohabiting

\footnotetext{
${ }^{2}$ In the Population Census 1991 and 2001 the union was considered as a 'factual marriage' only if the spouses explicitly declared that they lived in cohabitation and at the same time were officially registered at the same place of residence. Because many young people officially live in their parental home or another place, or because they simply do not want to state that they are cohabiting, the data are underestimated to an unknown extent (Rychtař́ková, 1994). The proportion of cohabiting women age 15-44 among those living in a partnership was 3.6\% according to the 1991 census and $7.2 \%$ according to the 2001 census (Zeman, 2003).
} 
women among all women living in unions at age 15-44 was 10\% (FFS, 1997), and the Generation and Gender Survey (GGS, 2005) places the figure in 2005 at $15 \%$. The proportion cohabiting is negatively correlated to the education of the women: according to the 1997 FFS survey, the proportion was 12\% among primary-educated women, 9\% among the secondary-educated and only $4 \%$ among the university-educated (women still in education were excluded). In 2005 , the respective proportions cohabiting were $17 \%$ for primary-educated, $14 \%$ for secondary-educated and $13 \%$ for university-educated. The increase in the proportion cohabiting was more pronounced among university educated women, but the proportion cohabiting is still negatively related to the level of education.

It is not clear what proportion of single mothers is cohabiting and how many of them are living alone. Lone mothers with children compose a socially emergent group of "incomplete families" and their proportion is much higher among lower educated women. Data from the Labour Force Survey 2005 show that 16\% of mothers aged 25-34 years lived alone, without a partner, and this figure even reached $31 \%$ among primary educated women. Among lower- and upper-secondary educated the figure was $14 \%$ and $20 \%$ respectively, and among university educated only $9 \%$ of women with a child or children were alone (CZSO, 2006c).

An unwanted or unplanned pregnancy, especially at a young age, can also seriously reduce and reschedule both the educational career and family formation processes. In the past 15 years, the spread of modern contraception and the improvement of sexual education contributed to a drop in teenage pregnancies and abortions, which were used during socialism as "contraception ex post". However, the phenomenon of unwanted pregnancy resulting in teenage motherhood still persists especially among girls from families of lower socioeconomic status, who then often enter the group of lone mothers (Vašková, 2006).

\subsection{Incompatibility of work and childrearing - family environment and family policy}

Two principal dimensions of incompatibility, cultural and structural, are responsible for the negative impact of education on family formation (Liefbroer and Corijn, 1999). In the Czech society, the relics of socialist state society interfere with the outcomes of fast market change accompanied by a broad change in values and attitudes in a post-modern world.

The highly secularised and increasingly consumerist Czech society had already become tolerant towards certain forms of non-traditional family behaviour before 1990, generally accepting abortions, premarital sex, and divorce. The opening and pluralisation of the society since 1990 have brought a modest growth in post-materialism accompanied by a 
change in the values and attitudes of individuals (Rabušic, 2001). Increasing tolerance towards deviations from the traditional patterns, such as homosexuality or extra-marital childbearing reflects the permissiveness of Czech society and the degree to which individualization proceeded (Sobotka et al., 2003).

On the other hand, female labour force participation, almost universal before 1990, has declined only slightly, to $51 \%$ of all women older than 15 years in 2005 , with another $4 \%$ on parental leave and $3 \%$ being house-wives (CZSO, 2006a) $)^{3}$. As opposed to the situation in Western Europe, a large majority of employed women work full-time - only 8.6 per cent of all employed women worked part-time in 2005 (CZSO, 2006a). The lack of opportunities for part-time employment constitutes a constraint for women who want to combine work and childcare.

There was a high level of institutionalised childcare during the socialist period, making it easier for women to combine childbearing (which occurred often at very young ages) with work. After 1990, the supply of nurseries for children younger than 3 years of age almost collapsed. In 2005 there were only 56 state-run nurseries, serving a total of 1,600 children (UZIS, 2006), whereas kindergartens are still widely available and used by about 90\% of children aged 3-5 years (CZSO, 2005).

On the other hand, the current social system is fairly generous and encourages mothers with young children to stay at home, contributing to the educational differences with regard to family formation: lower educated women with worse career prospects and lower wages tend to stay home with children, while better educated women postpone or forego childbearing on behalf of their professional careers. Higher educated women also tend to return to work from parental leave earlier than the lower educated (Kuchařová et al., 2006).

After 1989, family policies were transformed and they lost their previous pronatalist orientation. Apart from the birth allowance, they ceased to be based on the number of children, being incorporated into broader social welfare policies aimed at reducing income inequality and poverty, and providing social security. During maternity leave women receive an allowance based on their previous salary (maximum EUR $466^{4}$ per month), and this leave is longer for lone mothers who confirm they are not living with a partner (37 weeks, as compared to 28 weeks for married or cohabiting mothers). Parents can then continue into

\footnotetext{
${ }^{3}$ The male labour force participation in 2005 was $69 \%$. Female wages are lower than male, but the difference has decreased since the nineties: in 2005 the median female wage was $81 \%$ of the male median wage (CZSO, 2006b).

${ }^{4}$ Values, actual for 2005, are expressed in euro (EUR), using exchange rate of CZK 28.5 to EUR 1.
} 
parental leave $e^{5}$ with allowances of about EUR 133 per month. The difference between the duration of maternity leave for lone mothers and for married/cohabiting ones leads to the situation where lone mothers could gain about EUR 700 in total because of staying longer on maternal leave before switching to parental leave (Soukupová, 2006). This in turn leads to the suspicion that some mothers, especially those of low socio-economic status, exploit or even misuse this policy measure. Since 2001, parental leave can also be taken by the father of the child, but merely $1 \%$ of parental allowances are paid to men; interestingly, this proportion is higher in regions with a higher unemployment rate (Nešporová, 2005) and higher among lower educated men (Kuchařová et al., 2006). The child allowances, paid to the child until it reaches the age of 15 (or until 26 when studying) are amongst the lowest in the EU, ranging from EUR 9 to 28 monthly. ${ }^{6}$

\subsection{Educational expansion}

Since the system change in 1989, the perception of the importance of education has increased substantially. The economic transformation has generated the need for a highly educated workforce and the investment in education became economically advantageous because of two things: the reduction in the risk of unemployment; and increasing income stratification ${ }^{7}$.

Broader opportunities for higher education have led to the extension of the period spent by young people in education, but the education at certain levels also lengthened. Between 1995 and 2004, the number of expected years spent in education increased by 2.7 years, to which primary and secondary education contributed 1.6 years and tertiary education contributed 1.1 years (OECD, 2006). The overall expected time spent in education thus increased from 14.3 in 1995 to 17 years in 2004, 16.9 for male and 17.1 for female (ibid.). Female participation in higher education rose faster than that of males, leading to the

\footnotetext{
${ }^{5}$ The paid parental leave in the Czech Republic is one of the longest in Europe - until the child is 4 years of age, with 3 years of granted job position. However, although the job position is reserved by law, in reality young childless women often face discrimination during job interviews. Also, mothers face regression in job position and in wages after returning from parental leave (Kuchařová et al., 2006). On the other hand, it is disadvantageous for employer to keep the position open where he is uncertain when, and if, the employee will return to work. The proportion returning to the reserved position is again higher among higher educated.

${ }_{6}^{6}$ More recently, as a result of the widely discussed decline in fertility and the formulation of new "National concept of family policy" (MLSA, 2005), some new pronatalist measures were introduced. The birth allowance doubled in 2006 and the parental allowances doubled in 2007. Since 2007 the monetary difference between maternity and parental allowance has become smaller, especially for women with lower previous wages (as maternity leave is computed as 69\% of woman's previous wage, whereas parental leave since 2007 has been fixed at $40 \%$ of mean wage).

${ }_{7}^{7}$ In 2005, the unemployment rate of $7.9 \%$ total was distributed extremely uneven through educational categories: among primary educated $26.7 \%$ of the workforce were looking for a job, among the two categories of secondary education it was $8.9 \%$ and $5.1 \%$ resp., and among university educated only $2.3 \%$ were unemployed (CZSO, 2006a). Figures for women were even higher; the gender unemployment gap is depicted by the total unemployment rate of $6.5 \%$ for males compared to $9.8 \%$ for females (ibid.). The wage level of university-educated employees rose from 134\% of the average wage in 1988 to $165 \%$ in 1996 (Večerník, 1999: 119) and to $170 \%$ in 2005 (CZSO, 2006b).
} 
levelling off of the proportions of males and females in university education - in the 20042005 academic year, 51\% of students in Czech universities were women (CZSO, 2005). The overall increase in the education of the female population is mirrored by the changing distribution of live births by education of mother, and distribution of women by highest attained education (Tables 2 and 3 ).

Table 2. Proportion of $1^{\text {st }}$ live births by education of mother

\begin{tabular}{|l|r|r|r|r|}
\hline \multicolumn{1}{|c|}{ Education of mother } & 1990 & 1995 & 2000 & \multicolumn{1}{c|}{2005} \\
\hline Primary & $10.3 \%$ & $12.5 \%$ & $10.5 \%$ & $10.1 \%$ \\
Secondary (no graduation) & $39.9 \%$ & $43.9 \%$ & $35.1 \%$ & $28.3 \%$ \\
Secondary (with graduation) & $41.2 \%$ & $35.1 \%$ & $43.2 \%$ & $45.9 \%$ \\
University & $8.6 \%$ & $8.4 \%$ & $11.2 \%$ & $15.7 \%$ \\
\hline Number (Total) & 62,374 & 44,522 & 43,904 & 49,930 \\
\hline
\end{tabular}

Source: own calculations based on data from the Czech Statistical Office

Table 3. Proportion of women at age 20-44 by finished level of education, 1991, 2001 and 2003

\begin{tabular}{|l|rrr|r|}
\hline Level of education & 1991 & 2001 & \multicolumn{1}{c|}{2003} & MEN 2003 \\
\hline Primary & $18.7 \%$ & $10.1 \%$ & $8.3 \%$ & $6.2 \%$ \\
Secondary (no graduation) & $35.9 \%$ & $34.3 \%$ & $33.8 \%$ & $47.8 \%$ \\
Secondary (with graduation) & $37.5 \%$ & $45.6 \%$ & $47.3 \%$ & $34.2 \%$ \\
University & $7.9 \%$ & $10.0 \%$ & $10.6 \%$ & $11.8 \%$ \\
\hline
\end{tabular}

Source: Census 1991 and 2001, Labour force survey 2003 (CZSO, 2004)

The educational homogamy is quite pronounced in the Czech Republic: according to the 2001 population census, $78 \%$ of women with lower education had a partner (married or cohabiting) with lower education and $63 \%$ of university educated women had a university graduate as a partner (Srb, 2006). Following the argumentation of Oppenheimer (2003), this could also be a reason why lower educated women tend to live and give birth outside marriage.

\subsection{Previous findings}

The family formation of distinct educational classes was analysed by Kantorová (2004) and Klasen and Launov (2006) using Family and Fertility Survey data from 1997. Kantorová has found that women with an upper-secondary or university education have comparatively lower first-birth risks than lower educated women. Moreover, after 1990 the impact of women's education on the timing of entry into motherhood has intensified and the period between the completion of studies and entry into motherhood has lengthened, especially among university graduates. Also, according to Klasen and Launov, higher education has an increasingly strong impact on the postponement of births and there is also the positive relationship between the level of education and the probability of exit from childbearing after the first child is born. 
According to Polášek (2005), the gap between non-marital childbirth and marriage has lengthened since the 1990s but this period is shorter for the university educated. Also, the proportion of unmarried mothers who never marry has increased, especially among lower educated women. Rychtaříková (2006) argued that the pronounced increase of non-marital fertility among low educated women has predominantly economic reasons, related to the actual setting of government policy towards families.

\section{Methods}

\subsection{Research question}

Women of different socio-economic status reacted differently to the economic and societal changes in the Czech Republic since the 1990s, and so the profound changes in family formation processes did not spread in the same way throughout the population. The educational attainment of mothers has been found to be the most important socio-economic determinant of fertility (Rychtaříková, 2004, Hamplová and Řeháková, 2006). This leads us to the research question of this paper: What is the role of women's education on the change in level and timing of fertility? Is there any clear pattern in respect of education? And what is the role of educational expansion in the family formation transition?

Our research strategy is sketched in Figure 2. For each level of education of women, we analyse the transitions from childlessness to motherhood using fertility life tables and from single status to marriage using nuptiality life tables. The life tables analysis substitutes for the two state-transitions indicated by dotted lines that are unable to be analysed due to lack of the data. Next, we introduce two hazard models, modelling the hazard of first conception as a function of duration since first marriage, and the hazard of first marriage as a function of duration since first conception. 
Figure 2: State-space diagram of family formation and the research instruments used
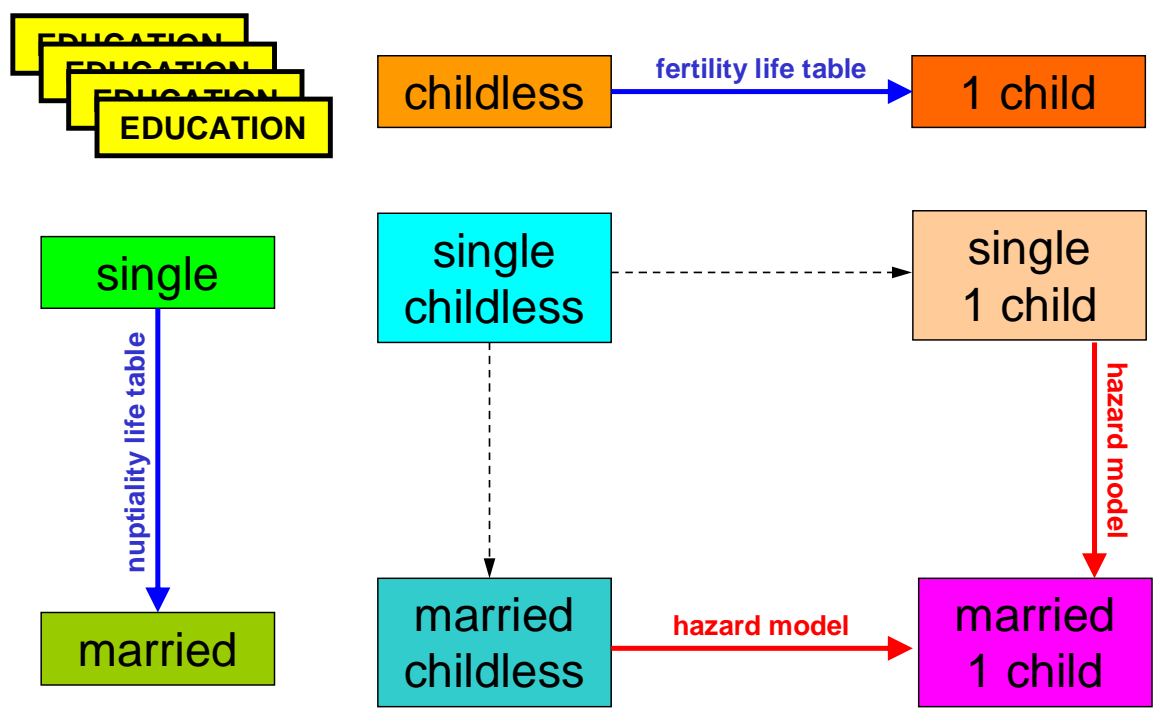

\subsection{Data}

We use individual data on births and marriages in 1991-2005 provided by the database of the Czech Statistical Office. The data contain several variables for each recorded birth (marriage), including the information on the woman's current attained education level.

For the computation of fertility and nuptiality life tables in two distinct periods, 1991 and 2001, we aggregate the data on first births and first marriages according to the age and educational attainment of the women, obtaining the occurrences. The exposures are taken from the Population and Housing Censuses 1991 and 2001. For nuptiality tables we use the population structure of women by age, educational attainment and marital status (keeping single women), for fertility tables we use the population structure of women by age, educational attainment and number of children ever born (keeping childless).

For the hazard modelling, the first live births and first marriages in the given period are linked according to the unique ID number of the woman. The date at first birth is recalculated as the date at conception, subtracting the number of weeks of gestation (only conceptions that result in live birth are considered). We consider the date at conception rather than birth date because the partners' decision making is already affected by the fact of pregnancy and pregnancy is also often a strong incentive for the entry into marriage.

Then we obtain two time series of data: firstly, the women who conceived as single, and later married (during pregnancy or after childbirth), or were censored in January 2006; secondly, the women who married childless (and non-pregnant) and conceived and gave birth to a first child inside marriage (or were censored). Mortality and migration are not taken into 
consideration: mortality is very low among women in the childbearing ages, and emigration is assumed to counterbalance with immigration.

We use four levels of finished education measured at the time of event (birth, marriage): primary education (including missing and unfinished basic education); secondary education without the "maturita" qualification (including vocational training); secondary education with the "maturita"; and university education ${ }^{8}$. Some researches recommend distinguishing between the educational investment and enrolment, i.e. to separate the effect of being in education from the effect of the obtained level of education (Blossfeld and Huinink, 1991, Hoem, 1986). There is also concern about the measurement of the education, time when measured (at survey, at event under investigation, time-varying), and the scale of measurement (finished level of education or the number of years of schooling). The best option is to measure education as a time-varying variable (Hoem and Kreyenfeld, 2006, Kravdal, 2004), which is nevertheless not fulfilled by our data. There is no time-varying characteristic on education available and no information about educational enrolment. However, our variable covers the "educational history" in the sense that we have information about the highest level of education at time of event. We do not have information about potential continuation of (or return to) educational enrolment. We assume that education is finished at first childbirth (see also Marini, 1984, Rindfuss et al., 1980), arguing that in the Czech Republic, education enrolment and childcare are generally incompatible (Kantorová, 2004, Klasen and Launov, 2006, Sobotka et al., 2003). It is less strong to assume that education is finished before first marriage, especially for the primary educated. However, the actual numbers of those who marry as primary educated and conceive the first child inside marriage are rather small. ${ }^{9}$

\subsection{Fertility and nuptiality life tables}

The life tables were computed using the parity and age intensities (occurrences/exposures) $\operatorname{method}^{10}$. First birth intensities for a given calendar year are computed as the number of

\footnotetext{
${ }^{8}$ We sometimes refer to the first two educational groups as "lower educated" and to the two latter as "higher educated". Also, we refer to the secondary education without graduation as "lower secondary" and to the secondary education with graduation as "upper secondary".

${ }_{9}^{9}$ Observing the data set we found that from women who have delivered both their $1^{\text {st }}$ and $2^{\text {nd }}$ children in $1991-2005,17 \%$ of primary educated and 5-7\% of the others progressed in education between $1^{\text {st }}$ and $2^{\text {nd }}$ childbirth. Among those who married childless in 1991-2005 as primary educated, 82\% progressed in education before childbirth, while among secondary educated it was $7-20 \%$.

${ }_{10}$ As shown by Park (1976), parity-adjusted cumulative birth rates (PATFR) have several advantages compared to conventional period total fertility rate (TFR). The fluctuations between periods are within more narrow limits and they can not exceed the (impossible) limit of 1,000 first-births per 1,000 women as the TFR of first-birth can do during baby-boom
} 
children of parity one born in given year to mothers at a given age (considered fertility life span 15-45 years), divided by the corresponding number of childless (parity zero) women ${ }^{11}$, i.e. (using notation of Park, 1976):

$$
\mathrm{f}_{1, \mathrm{x}}=\mathrm{b}_{1, \mathrm{x}} / \mathrm{w}_{0, \mathrm{x}}
$$

where $\mathrm{f}_{1, \mathrm{x}}$ is the probability that a woman of parity 0 at age $\mathrm{x}$ will bear her first child between ages $\mathrm{x}$ and $\mathrm{x}+1, \mathrm{w}_{0, \mathrm{x}}$ is the number of women of parity 0 at age $\mathrm{x}$ and $\mathrm{b}_{1, \mathrm{x}}$ is the number of the first order births born to women between ages $\mathrm{x}$ and $\mathrm{x}+1$. Further computations are made as follows:

- root table number of childless women at age $15: \mathrm{W}_{0,15}=1$

- table number of births: $\mathrm{B}_{1, \mathrm{x}}=\mathrm{f}_{1, \mathrm{x}} * \mathrm{~W}_{0, \mathrm{x}}$

- table number of childless women: $\mathrm{W}_{0, \mathrm{x}+1}=\mathrm{W}_{0, \mathrm{x}}-\mathrm{B}_{1, \mathrm{x}}$

- age-parity index of total fertility: $\operatorname{PATFR}_{1}=\Sigma_{\mathrm{x}} \mathrm{B}_{1, \mathrm{x}}$

- ultimate childlessness: $\mathrm{W}_{0,46}=\left(1-\mathrm{PATFR}_{1}\right)$

The nuptiality life tables use a similar concept, with the intensities computed as the number of first marriages divided by the number of single women at a given age (s):

$$
\mathrm{n}_{\mathrm{s}, \mathrm{x}}=\mathrm{m}_{\mathrm{s}, \mathrm{x}} / \mathrm{w}_{\mathrm{s}, \mathrm{x}}
$$

Both tables are computed for 1991 and 2001 and for 4 categories of education separately.

\subsection{Hazard model definition}

We further analyse the transition of women who are either single mothers (or pregnant), or childless married women. For this purpose we introduce two piecewise linear models of the

periods. While TFR can be described as "uncontaminated by the influence of the age distribution" (Ryder, 1965: 297), the PATFR we could describe as "uncontaminated by the influence of the parity distribution".

11 The potential discordance between data from vital statistics (occurrences) and censuses (exposures) concerning overestimation of the number of childless women with primary (and finished) education at young ages has been overcome by: $1 /$ adjusting exposure population for education reached during the year instead of at the beginning of the year; $2 /$ adjusting the numbers of primary educated women aged 15-20 for those still enrolled in education who will eventually progress to higher education category. 
important transitions. For the analysis of the process of entering marriage after conception of first child we use the following hazard model with one duration spline:

$$
\log m_{i}(t)=y(t)+\Sigma_{k} \alpha_{k} x_{i k}
$$

where $m_{i}$ is the intensity of first marriage for the individual $i, t$ is the duration variable (time since first child conception) and $y$ is a spline that picks up the effect of such duration. The sum represents the set of time-fixed covariates $x$ indexed by $k$, with a corresponding vector of parameters $\alpha$. Time is computed as date of first marriage (or censoring date, which is January 2006) minus the date of first birth conception and is measured in months. This model includes premarital conceptions for marital births.

For the analysis of the process of first child conception inside marriage we use the following hazard model:

$$
\log b_{j}(\tau)=z(\tau)+\Sigma_{l} \beta_{l} w_{j l}
$$

where $b_{j}$ is the intensity of first birth conception for individual $j, \tau$ is the duration variable (time since first marriage) and $z$ is a spline that picks up the effect of this duration. The sum represents the set of time-fixed covariates $w$ indexed by $l$, with a corresponding vector of parameters $\beta$. Time is computed as date of first birth conception (or censoring date, which is January 2006) minus the date of first marriage (in months). This model includes also children conceived during the month of marriage (honeymoon), but not those children born after marriage who were conceived before marriage. All computations were made using aML software; data preparation was made in Stata statistical software.

Several explanatory variables were inputted into the models, all of them time-fixed at the time of initial event. In the first place we use the information on education of woman, defined above. As time variables we use individual age of woman in 5-year groups, and the period. The differences between the educational groups can be influenced by the variations in timing of marriage and childbearing in respect of personal age. Less educated women usually have children at a younger age, when it is more likely that they are still non-married, while higher educated women tend to give birth at older ages, when they are more likely to be 
already married. In order to pick up the role of historic time we control for the effect of period, divided into three five-year periods (1991-1995, 1996-2000 and 2001-2005).

Further, we control for the region of woman's residence, dividing the Czech Republic into 4 territories $^{12}$ : The control region consists of central, southern and eastern Bohemia; the second is the North West, which is composed of districts notorious for its adverse socioeconomic climate (heavy industry, unfinished restructuralisation, high unemployment, worse ecological environment, lower socio-economic status of inhabitants), resulting in adverse demographic behaviours including higher non-marital fertility (Poppová, 2004). The third region is situated in the eastern part of the Czech Republic - Moravia; it is a region with more conservative socio-demographic behaviour and a higher religious affiliation among the population, higher marital rates and also lower proportion of non-marital childbearing. The fourth region is the capital, Prague, with its post-modern, metropolitan behaviour patterns. For the model of first birth conception inside marriage we also included the information about the level of husband's education and about his previous marital status. In case of repeated marriage of the male the fertility plans of the couple could be seriously limited.

\section{RESULTS}

The first part of this chapter focuses on the analysis of the drop in level and postponement of timing of first birth (section 5.1.) and first marriage (5.2.) using life table analysis. The second part investigates the nuptiality behaviour of those who conceive a child outside marriage (5.3.) and the fertility behaviour of those who marry childless and non-pregnant (5.4.), using hazard modelling.

\subsection{Level and timing of first birth according to the education of mother - fertility life tables 1991 and 2001}

Here we present aggregate indicators obtained from the life tables based on parity and ageadjusted intensities of period (cross-sectional cohort) fertility. The PATFR 1 is the age-parity index of total fertility rate of first order, which we further divide into two age categories to

\footnotetext{
${ }^{12}$ North-West region is composed of four NUTS3 regions (Karlovarský, Ústecký, Liberecký and Moravskoslezský kraj), Central region consists of five NUTS3 regions (Plzeňský, Středočeský, Jihočeský, Královehradecký and Pardubický kraj), NUTS3 region Prague stands alone and East region consists of four Moravian NUTS3 regions (Vysočina, Jihomoravský, Olomoucký and Zlínský kraj). By region variable we control for otherwise unobserved characteristics of the behaviour of the individuals given by characteristics other than educational ones, e.g. by economic level, prevalent values and attitudes, conditions of society, and religious characteristics. According to Hamplová and Řeháková (2006), the odds of bearing a child outside marriage are higher in regions with higher unemployment and higher proportion of urban population, while the mean salaries were found to be statistically unimportant in this sense.
} 
observe the "recuperation", as commonly referred to for fertility catch-up among those who postponed it until after age 30 (Lesthaeghe and Moors, 2000). The complement of PATFR 1 to 1 captures the proportion of ultimately childless. The table further contains indicators of timing and postponement of fertility: the mean age of mother at first childbirth and the proportion of first children born after age 30 .

Table 4. Fertility life tables indicators, 1991 and 2001

\begin{tabular}{|l|rrrr|r|}
\hline \multicolumn{1}{|c|}{ 1991-Education } & \multicolumn{1}{c}{ Prim } & Sec- & Sec+ & \multicolumn{1}{c|}{ Uni } & \multicolumn{1}{c|}{ Total } \\
\hline PATFR $_{1}$ & 0.87 & 0.95 & 0.92 & 0.92 & $\mathbf{0 . 9 3}$ \\
\hline - realised at age 15-29 & 0.83 & 0.92 & 0.84 & 0.80 & $\mathbf{0 . 8 8}$ \\
- realised at age 30-45 & 0.03 & 0.03 & 0.08 & 0.11 & $\mathbf{0 . 0 5}$ \\
\hline Ultimate childlessness (\%) & 13 & 5 & 8 & 8 & $\mathbf{7}$ \\
Mean age (1) & 20.8 & 21.4 & 23.6 & 25.9 & $\mathbf{2 2 . 6}$ \\
1st ch.f. realised after age 30 (\%) & 4 & 3 & 8 & 12 & $\mathbf{5}$ \\
\hline
\end{tabular}

\begin{tabular}{|l|rrrr|r|}
\hline \multicolumn{1}{|c|}{ 2001-Education } & \multicolumn{1}{c|}{ Prim } & Sec- & Sec+ & \multicolumn{1}{c|}{ Uni } & \multicolumn{1}{c|}{ Total } \\
\hline PATFR $_{1}$ & 0.81 & 0.84 & 0.74 & 0.76 & $\mathbf{0 . 7 7}$ \\
\hline - realised at age 15-29 & 0.77 & 0.71 & 0.51 & 0.39 & $\mathbf{0 . 5 7}$ \\
- realised at age 30-45 & 0.04 & 0.13 & 0.24 & 0.37 & $\mathbf{0 . 2 1}$ \\
\hline Ultimate childlessness (\%) & 19 & 16 & 26 & 24 & $\mathbf{2 3}$ \\
Mean age (1) & 21.6 & 24.9 & 28.0 & 29.8 & $\mathbf{2 6 . 8}$ \\
1st ch.f. realised after age 30 (\%) & 5 & 15 & 32 & 49 & $\mathbf{2 7}$ \\
\hline
\end{tabular}

\begin{tabular}{|l|rrrr|r|}
\hline \multicolumn{1}{|c|}{ Change 2001-1991 } & \multicolumn{1}{c|}{ Prim } & Sec- & \multicolumn{1}{c|}{ Sec+ } & \multicolumn{1}{c|}{ Uni } & \multicolumn{1}{c|}{ Total } \\
\hline PATFR $_{1}$ & -0.05 & -0.11 & -0.17 & -0.16 & $\mathbf{- 0 . 1 5}$ \\
\hline - realised at age 15-29 & -0.07 & -0.21 & -0.34 & -0.42 & $\mathbf{- 0 . 3 1}$ \\
- realised at age 30-45 & +0.01 & +0.10 & +0.16 & +0.26 & $\mathbf{+ 0 . 1 6}$ \\
\hline Ultimate childlessness (\%) & +5 & +11 & +17 & +16 & $\mathbf{+ 1 5}$ \\
Mean age (1st) & +0.7 & +3.5 & +4.4 & +3.9 & $\mathbf{+ 4 . 3}$ \\
1st ch.f. realised after age 30 (\%) & +2 & +13 & +24 & +37 & $\mathbf{+ 2 1}$ \\
\hline
\end{tabular}

From our data is clear that the deepest drop in fertility level occurs among higher educated women, for whom the proportion of childless increased from $8 \%$ in 1991 to around $25 \%$ in 2001 . The main driving force behind this drop was the postponement of fertility onset until later ages, as indicated by the increase in mean age by $4-4.5$ years to 28 years among higher secondary educated and to almost 30 years among university graduated. The proportion of university educated women who start their fertility path after their $30^{\text {th }}$ birthday increased to almost 50\%, among secondary educated women with graduation the proportion increased by one third. On the contrary, primary educated women experienced a somewhat smaller decrease in fertility level, which was lower anyway, and more importantly there was virtually no increase in mean age at first childbirth, which was only 21.6 years in 2001 . The proportion of primary educated who had their first childbirth in their thirties remains very low, around 5\%. The fertility level of secondary educated without graduation is the highest of 
all educational groups, but they also experienced some postponement of fertility, although the proportion marrying and conceiving their first child after age 30 remains low.

Apart from a pronounced drop in the level of fertility and its postponement until later ages, there are also some signs of its recuperation at older ages. Between 1991 and 2001 about half of the fertility level drop at age 15-29 was compensated by its increase at age 3045.

\subsection{Level and timing of first marriage according to the education of bride - nuptiality life tables 1991 and 2001}

For nuptiality, its decrease in level and its postponement were more pronounced than those of fertility and they were more evenly distributed across the educational groups. The total first marriage intensity dropped by 0.2 on average and the proportion ultimately single increased from $7-17 \%$ in 1991 to $23 \%$ among university educated and even to $40 \%$ among primary educated women. Mean age rose by 3.5-4.5 years and the proportion marrying in their thirties increased to $19-28 \%$ among all educational groups, suggesting that primary educated women also tend to postpone marrying until later ages, even though they usually have children at much younger ages.

Table 5. Nuptiality life tables indicators, 1991 and 2001

\begin{tabular}{|l|rrrr|r|}
\hline \multicolumn{1}{|c|}{ 1991 - Education } & \multicolumn{1}{c|}{ Prim } & Sec- & Sec+ & \multicolumn{1}{c|}{ Uni } & \multicolumn{1}{c|}{ Total } \\
\hline Total first marriage intensity & 0.83 & 0.94 & 0.92 & 0.93 & $\mathbf{0 . 9 2}$ \\
Mean age at first marriage & 23.4 & 22.1 & 23.7 & 25.3 & $\mathbf{2 3 . 2}$ \\
Nuptiality realised after age $30(\%)$ & 8 & 4 & 8 & 7 & $\mathbf{6}$ \\
\hline
\end{tabular}

\begin{tabular}{|l|rrrr|r|}
\hline \multicolumn{1}{|c|}{ 2001 - Education } & \multicolumn{1}{|c|}{ Prim } & \multicolumn{1}{c|}{ Sec- } & Sec+ & \multicolumn{1}{c|}{ Uni } & \multicolumn{1}{c|}{ Total } \\
\hline Total first marriage intensity & 0.60 & 0.76 & 0.74 & 0.77 & $\mathbf{0 . 7 3}$ \\
Mean age at first marriage & 26.8 & 26.5 & 28.3 & 28.9 & $\mathbf{2 7 . 8}$ \\
Nuptiality realised after age 30 (\%) & 21 & 19 & 25 & 28 & $\mathbf{2 3}$ \\
\hline
\end{tabular}

\begin{tabular}{|l|rrrr|r|}
\hline \multicolumn{1}{|c|}{ Change 2001-1991 } & Prim & Sec- & Sec+ & \multicolumn{1}{c|}{ Uni } & \multicolumn{1}{c|}{ Total } \\
\hline Total first marriage intensity & -0.23 & -0.18 & -0.18 & -0.16 & $-\mathbf{0 . 1 9}$ \\
Mean age at first marriage & +3.4 & +4.4 & +4.5 & +3.6 & $\mathbf{+ 4 . 6}$ \\
Nuptiality realised after age 30 (\%) & +13 & +15 & +17 & +21 & $\mathbf{+ 1 7}$ \\
\hline
\end{tabular}

The impact of education on the levels of fertility and nuptiality works in opposite directions: the level of fertility is lower among higher educated and higher among lower educated, whereas the level of nuptiality is lowest among primary educated and higher among both the secondary and university groups. The age at family formation is strongly correlated with the level of education, adding approximately 2-3 years to mean age at childbearing and $1 / 2-1$ year to mean age at marriage at each educational level. The different 
timing and sequencing of marriage and childbearing is also demonstrated by the following fact: among lower educated the mean age at marriage is several years higher than the mean age at childbirth, but among higher educated the mean ages are equal, or they show the opposite trend.

\subsection{The transition to first marriage according to the time since first-child conception}

In this section we present the analysis of the transition to first marriage, using hazard modelling. A total of 421,572 observations (conceptions of single women between 1991 and 2005 ) entered this model, resulting in 251,045 first marriages and 170,527 observations censored at the end of the observation period (January 2006). This model covers premarital conceptions and non-marital births, whether later "legitimised" or not.

The baseline of first marriage hazard by duration since conception for two distinct periods, 1991-1995 and 2001-2005, is displayed in Figure 3. We can notice an accentuated risk of marriage just during the pregnancy, with a peak around 6 months after conception, and a low and constant risk of marriage after the birth of a child. Concerning period change, the risk of "shotgun" marriage has been reduced in the more recent period while the risk of later "legitimisation", although much lower than risk of marriage during pregnancy (and thus not well manifested in the Figure), significantly increased.

Figure 3: Baseline hazard of first marriage modelled according to the duration since first child conception (models $3 a$ and $3 b$ )

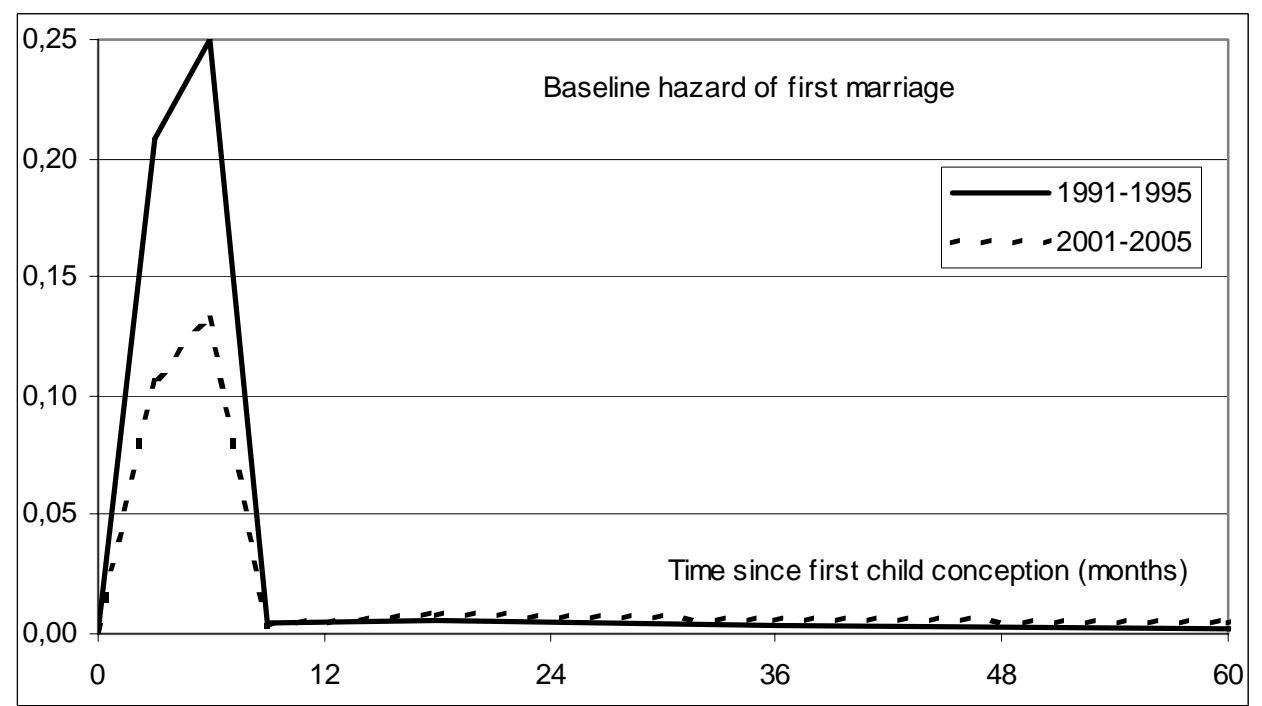


Table 6. Hazard of first marriage modelled by the duration since first child conception

\begin{tabular}{|c|c|c|c|c|c|}
\hline \multirow{2}{*}{$\begin{array}{l}\text { Model estimates } \\
\text { Variables }\end{array}$} & 1 & 2 & 3 & 3a: 1991-95 & 3b: 2001-05 \\
\hline & rel.risk & rel.risk & rel.risk & rel.risk & rel.risk \\
\hline EDUCATION WOMAN - primary & 0.53 & 0.45 & 0.47 & 0.56 & 0.47 \\
\hline secondary (no graduation) & 1 & 1 & 1 & 1 & 1 \\
\hline secondary (with graduation) & 1.01 & 1.20 & 1.20 & 1.09 & 1.41 \\
\hline university & 0.67 & 1.20 & 1.17 & 0.85 & 1.84 \\
\hline AGE WOMAN -less than 20 & & 1.33 & 1.30 & 1.51 & 0.77 \\
\hline $20-24$ & & 1 & 1 & 1 & 1 \\
\hline $25-29$ & & 0.59 & 0.63 & 0.38 & 0.90 \\
\hline $30-34$ & & 0.33 & 0.35 & 0.26 & 0.53 \\
\hline $35-39$ & & 0.18 & 0.19 & 0.21 & 0.23 \\
\hline $40+$ & & 0.14 & 0.15 & 0.14 & 0.14 \\
\hline REGION -Prague & & & 0.83 & 0.89 & 0.83 \\
\hline Central-Southern & & & 1 & 1 & 1 \\
\hline North-West & & & 0.75 & 0.83 & 0.68 \\
\hline East & & & 1.03 & 1.03 & 1.07 \\
\hline PERIOD 1991-1995 & & & 0.90 & & \\
\hline $1996-2000$ & & & 1 & & \\
\hline $2001-2005$ & & & 0.69 & & \\
\hline Log-likelihood & -931478 & -915989 & -911359 & & \\
\hline
\end{tabular}

Note: All estimates are statistically significant on $>99 \%$ level except those printed in italics

Table 6 shows the relative risks of marriage ${ }^{13}$ estimated from modelling the hazard of marriage after first birth conception. Three consecutive models were computed, with the most saturated one recalculated separately for the two distinct periods, 1991-95 and 2001-05 to determine the change in relative risks over time. Emerging from the first and second models is the importance of individual time: the crude effect of university education decreases the risk of first marriage, but only because university educated women bear children at older ages. After controlling for age, the hazard of marriage seems to correlate with the level of education: higher educated women have a $20 \%$ higher propensity to marry than lower-secondary educated, while those with primary education have less than half the risk in this relation. Comparing distinct periods, the risk of marriage first slowly increased by $10 \%$ during the nineties, but then suddenly dropped by more than $30 \%$ after year 2000 . The drop was especially pronounced among lower-educated women and teenagers, while the relative risk of marrying of those aged 25-34 increased more than two-fold. The age distribution of marital risk changed, postponing the focus towards later ages. Important is also the relative progress in propensity to marry among the higher educated, who are becoming increasingly prone to marry after pregnancy or birth of a child, while primary educated women tend to stay single. Concerning regional division there is no surprise that marriages in north-western parts of the Czech Republic and in Prague are becoming relatively less popular.

\footnotetext{
${ }^{13}$ Risk of marriage means the risk of marrying among women who became pregnant while being single. The baseline hazard values are not published.
} 


\subsection{The transition to first conception according to the time since first marriage}

A total of 361,227 observations (women that experienced first marriages when childless and non-pregnant between 1991 and 2005) entered this model, resulting in 219,696 conceptions and 141,531 observations censored. This model covers conceptions during honeymoon and all marital childbirths except those conceived pre-maritally.

The baseline of the hazard of child conception by duration since marriage is displayed in Figure 4. Here we see the maximum conception risk just after marriage, with an almost linearly decreasing risk during the following months and years. In the more recent period the peak in the first year of marriage is less pronounced.

Figure 4: Baseline hazard of first conception modelled according to the duration since marriage (model $3 a$ and $3 b$ )

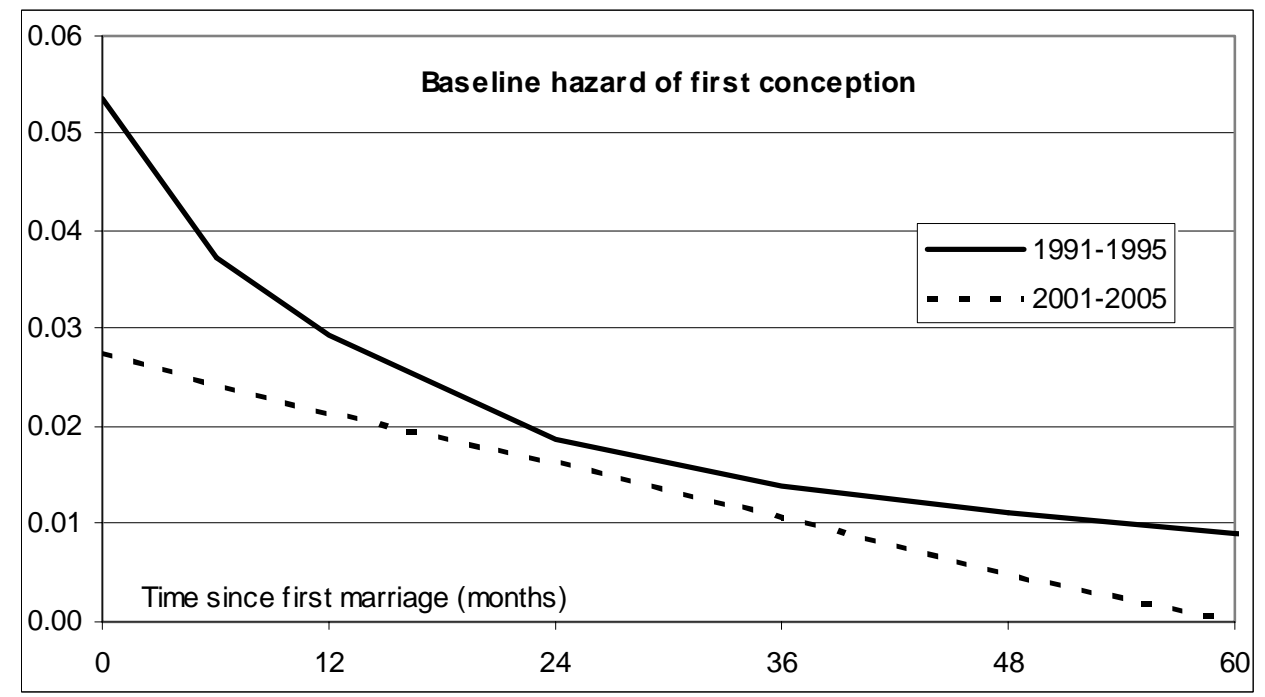

Table 7 shows the relative risk of conception ${ }^{14}$ estimated by modelling the hazard of first birth conception in marriage. Again, three consecutive models were computed, with two more for the two distinct periods separately. Here, the educational differences are much less pronounced. Primary educated are less likely to have children in marriage while the three other groups are more equal in their relative risks. The risk of becoming pregnant in marriage recently dropped by one quarter compared to previous periods and the age distribution again shifted towards later ages, and became more equally distributed. Regional division reveals a known pattern: women from Prague and from "problematic" regions are less likely to conceive in marriage. Concerning the characteristics of the husband, their educational attainment was found to be much less important for the marital fertility than those of women:

\footnotetext{
${ }^{14}$ Risk of conception means the risk of becoming pregnant for women who married childless and non-pregnant. The values of baseline hazard are not published.
} 
Only where the husband is in the primary education group does the relative risk of conception seem to be reduced. The marital fertility where the husband has repeated marriage is $15-30 \%$ lower.

Table 7. Hazard of first birth conception modelled by the duration since marriage

\begin{tabular}{|c|c|c|c|c|c|}
\hline \multirow{2}{*}{$\begin{array}{l}\text { Model estimates } \\
\text { Variables }\end{array}$} & 1 & 2 & 3 & 3a: $1991-95$ & 3b: 2001-05 \\
\hline & rel.risk & rel.risk & rel.risk & rel.risk & rel.risk \\
\hline \multirow{4}{*}{$\begin{array}{l}\text { EDUCATION WIFE-primary } \\
\text { secondary (no graduation) } \\
\text { secondary (with graduation) } \\
\text { university } \\
\end{array}$} & 0.79 & 0.82 & 0.82 & 0.89 & 0.70 \\
\hline & 1 & 1 & 1 & 1 & 1 \\
\hline & 1.00 & 1.03 & 1.05 & 1.05 & 1.04 \\
\hline & 1.00 & 1.18 & 1.18 & 1.29 & 1.05 \\
\hline \multirow{2}{*}{$\begin{array}{l}\text { AGE BRIDE less than } 20 \\
20-24\end{array}$} & & 1.15 & 1.09 & 1.10 & 1.02 \\
\hline & & 1 & 1 & 1 & 1 \\
\hline $25-29$ & & 0.83 & 0.93 & 0.72 & 1.14 \\
\hline $30-34$ & & 0.50 & 0.59 & 0.40 & 0.91 \\
\hline $35-39$ & & 0.19 & 0.23 & 0.16 & 0.38 \\
\hline $40+$ & & 0.01 & 0.01 & 0.01 & 0.02 \\
\hline \multirow{4}{*}{$\begin{array}{l}\text { EDUCATION HUSBAND-primary } \\
\text { secondary (no graduation) } \\
\text { secondary (with graduation) } \\
\text { university }\end{array}$} & & & 0.98 & 1.01 & 0.81 \\
\hline & & & 1 & & 1 \\
\hline & & & 0.99 & 1.00 & 0.96 \\
\hline & & & 1.00 & 1.04 & 0.94 \\
\hline \multirow{2}{*}{$\begin{array}{l}\text { STATUS HUSBAND single } \\
\text { divorced/widowed }\end{array}$} & & & 1 & 1 & 1 \\
\hline & & & 0.72 & 0.68 & 0.86 \\
\hline \multirow[t]{2}{*}{ REGION-Prague } & & & 0.81 & 0.80 & 0.85 \\
\hline & & & 1 & 1 & 1 \\
\hline North-West & & & 0.89 & 0.88 & 0.91 \\
\hline East & & & 1.04 & 1.05 & 1.03 \\
\hline \multirow{3}{*}{$\begin{array}{l}\text { PERIOD 1991-1995 } \\
1996-2000 \\
2001-2005\end{array}$} & & & 1.05 & & \\
\hline & & & 1 & & \\
\hline & & & 0.77 & & \\
\hline Log-likelihood & -1084961 & -1076084 & -1073176 & & \\
\hline
\end{tabular}

Note: All estimates are statistically significant on $>99 \%$ level except those printed in italics

\section{Conclusions}

In this article we argue that social and economic changes in the past fifteen years have influenced distinct socio-economic categories of women differently. We have shown that the transition of family formation behaviours was not uniform but rather dependent on the educational level of women. The number of possible reasons and impacts is manifold. A high female labour participation rate combined with the traditionally uneven division of gender roles has persisted in the Czech society even after the end of the previous regime. The difficulty of combining work and family, however, increased among higher educated women with more highly-rated jobs; thus the relative costs of childbearing have become higher. On the other hand, the current setting of family policy makes it more advantageous for low educated women with poor employment prospects to choose childbearing in place of a career. The value change of post-modern society changed attitudes towards cohabitation and non-marital childbearing and to alternative lifestyles in general. Marriage lost its universal connection with childbearing and family formation. 
The impact of education on family formation has been intensified by the educational expansion since the 1990s: the increasing proportion of women attending and finishing higher-secondary and tertiary education has gradually enlarged their distribution in the population, and the rise in the mean number of years spent in education itself postponed the onset of family formation. Educational expansion thus contributed to the general decrease in level of fertility and nuptiality and to the postponement of family formation to later ages.

\subsection{Changes in family formation since the early $1990 \mathrm{~s}$}

The drop in fertility levels and the postponement of childbearing was concentrated among higher educated women, while for primary educated almost no change was identified. On the other hand, both a substantial drop in nuptiality levels and a postponement of marriage until later ages could be detected throughout the full educational spectrum.

The increase in the proportion of non-marital births was especially pronounced among primary educated women. Most of the increase should be attributed to the increase in the interval between conception and marriage: other than in the past, when pregnancy was a strong impetus to marry promptly, in recent times women tend to stay single, either in cohabitation or even as lone mothers, either in order to marry later or to stay out-of-marriage forever. The proportion of cohabiting or lone mothers is strongly increasing among the lower educated.

Comparing the period 2001-2005 with 1991-1995, we found evidence for a decrease of risk of marriage after conception, especially among lower educated women and among teenage mothers. On the contrary, a relative increase in risk was observed among the higher educated and in the age group 25-34. There is also an evidence for a decrease in risk of conception after marriage throughout the period. Here, the risk is lower for primary educated compared to all other educational groups and the same is true when grouped according to the education of the husband. Again, the relative risk increased in the age group 25-34.

Regional patterns are quite clear, in north-western regions and in the capital of Prague the risks of first conception and marriage are relatively lower than in the central and eastern part of the Czech Republic.

\subsection{The role of educational attainment in the family formation process}

University educated women were found to be the most conservative in the sequencing of conception and marriage: they still tend to marry during pregnancy and they often even 
conceive their first child after marriage. On the other hand, they are the "trendsetters" in the sense of fertility drop and postponement.

Women in the group secondary educated with graduation follow the trends and patterns of behaviour of their highest educated counterparts, their level of fertility is the lowest from all educational groups and their mean age at family formation is above age 28 .

The behaviour of the secondary educated without graduation is closer to the average than to that of the lowest educated. Their fertility level is the highest of all educational groups, but they also experienced a moderate postponement of both fertility and nuptiality, although the proportion marrying and conceiving the first child after age 30 remains low.

Primary educated women form the most distinct group, tending to be lone mothers or to cohabit even after childbirth. The persisting high fertility at a young age along with the most pronounced drop in nuptiality levels, the disappearance of marriage after conception and the low risk of conception within marriage led to an increase of the proportion of first children born outside marriage to $80 \%$ in 2005 .

\subsection{Comparison with other studies}

Our analysis confirmed findings from other countries about the negative effect of women's education on the entry into parenthood (Rindfuss et al., 1980, 1996, Liefbroer and Corijn, 1999, Kreyenfeld, 2000). We also confirmed the findings of Kantorová (2004) and Klasen and Launov (2006), who analysed more detailed data from the Female and Fertility Survey data from 1997 and who found that women with an upper-secondary or university education have comparatively lower first-birth risks than the lower educated and that after 1990 the impact of women's education on timing of entry into motherhood intensified.

Increasing educational differences in the Czech Republic during the period 19912001 are in accordance with findings from Norway 1971-2001 (Lappegård and Rønsen, 2005) and the USA 1963-1989 (Rindfuss et al., 1996). The latter study found that the proportion of fertility occurring after age 30 is related positively to education, and while this proportion increased to almost 50\% among college graduates, only a limited change was observed among those with some college education and virtually none among those with less education (ibid.: 283); our findings were surprisingly similar.

Contrary to some studies (e.g. Liefbroer and Corijn, 1999), the level of women entering marriage was found to be the lowest among primary educated women in the Czech Republic. However, the fact that higher education postpones marriage until later ages was also found by Marini, 1984, Blossfeld and Jaeninchen, 1992, Liefbroer and Corijn, 1999. 


\subsection{Discussion}

Research usually tends to search for a general explanation of the transitional behaviour, but as we have shown, women of different educational levels have been reacting differently to the social and economic changes in the Czech Republic since the 1990s. Concerning recently emerging changes in family formation behaviours, two different types of "trendsetters" were identified in Czech society. The trendsetters of non-marital childbearing are mothers with primary education who frequently have children in cohabitation or as lone mothers. The trendsetters of fertility postponement are university and higher-secondary educated, who postpone the childbearing and marriage until after the age of 30 , but on the other hand they are behaving traditionally by timing the first childbirth inside marriage. The number of possible reasons for family formation transition is manifold, ranging from the changing economic roles of women through current setting of family policy to the post-modern value changes. The impacts are further enforced by educational expansion since the 1990s. There is no general explanation of the transitional behaviour, as women of different education levels are reacting differently to the social and economic changes.

\section{ACKNOWLEDGEMENTS}

I am thankful to Anna Štastná (Research Institute for Labour and Social Affairs, Prague), for providing me with the figures from Generations and Gender Survey 2005, to Jiři Vejrych (Czech Statistical Office) for providing me with the results of Population Census 1991 and 2001, and to Craig Meulen for language editing of the text. This research was conducted during my study visit at the Max Planck Institute for Demographic Research, Rostock. I would like to thank the members of Laboratory of Contemporary European Fertility and Family Dynamics for their useful comments on earlier draft of the paper.

\section{REFERENCES}

Billari, F. C. and D. Philipov, 2003. Mutual relationships between education and women's entry into a first union: the case of Central and Eastern Europe. In.: I. E. Kotowska and J. Jóźwiak. Population of Central and Eastern Europe. Challenges and Opportunities. European Population Conference, 26-30 August 2003. Warsaw: 201-218.

Blossfeld, H.-P. and J. Huinink, 1991. Human capital investment or norms of role transition? American Journal of Sociology 97: 143-168. 
Blossfeld, H.-P. and U. Jaeninchen, 1992. Educational expansion and changes in women's entry into marriage and motherhood in the Federal Republic of Germany. Journal of Marriage and the Family 54: 302-315.

CZSO, 2004. Výsledky ad hoc modulu 2003 o celoživotním vzdělávání. Czech Statistical Office, Prague.

CZSO, 2005. Schools and School Establishments in School Year 2004/2005. Czech Statistical Office, Prague.

CZSO, 2006a. Employment and Unemployment in the CR as Measured by the Labour Force Sample Survey Annual Averages for 2005. Czech Statistical Office, Prague.

CZSO, 2006b. Structure of Earnings Survey 2005. Czech Statistical Office, Prague.

CZSO, 2006c. Formování a rozpad domácností z výsledků výběrových šetření pracovních sil 2002 2005. Czech Statistical Office, Prague.

Fialová, L. and M. Kučera, 1997. The main features of population development in the Czech Republic during the transformation of society. Czech Sociological Review 5(1): 93-111.

FFS, 1997. Fertility and Family Survey 1997. Czech Republic.

GGS, 2005. Generations and Gender Survey 2005. Czech Republic.

Gustafsson, S., 2001. Optimal age at motherhood. Theoretical and empirical considerations on postponement of maternity in Europe. Journal of Population Economics 14: 225-247.

Hamplová, D., 2003. Marriage and educational attainment: A dynamic approach to first union formation. Czech Sociological Review 39(6): 841-863.

Hamplová, D. (ed.), 2006. Mimomanželská plodnost v České republice po roce 1989: sociální a ekonomické souvislosti. [Non-Marital Fertility in the Czech Republic after 1989: The Social and Economic Context]. Institute of Sociology of the Academy of Sciences of the Czech Republic, Prague.

Hamplová, D. and B. Řeháková, 2006. Mimomanželská plodnost: individuální charakteristiky žen a vliv regionu. In.: Hamplová, D. (ed.) (2006).

Hoem, J. M., 1986. The impact of education on modern family-union initiation. European Journal of Population 2: 113-133.

Hoem, J. M. and M. Kreyenfeld, 2006. Anticipatory analysis and its alternatives in life-course research. Demographic Research 15(16-17): 461-498.

Kantorová, V., 2004. Education and entry into motherhood: The Czech Republic during state socialism and the transition period (1970-1997). Demographic Research: Special Collection 3(10): 245-274.

Klasen, S. and A. Launov, 2006. Analysis of the determinants of fertility decline in the Czech Republic. Journal of Population Economics 19: 19-54.

Konietzka, D. and Kreyenfeld, M., 2001. Non-marital births in East Germany after unification. MPIDR Working Paper WP-2001-027, Rostock. 
Kravdal, Ø., 2004. An illustration of the problems caused by incomplete education histories in fertility analyses. Demographic Research: Special Collection 3(10): 135-154.

Kreyenfeld, M., 2000. Educational attainment and first births: East Germany before and after unification. MPIDR Working Paper WP-2000-011, Rostock.

Kuchařová et al., 2006. Zaměstnání a péče o malé děti z perspektivy rodičů a zaměstnavatelů. Výzkumný ústav práce a sociálních věcí, Praha.

Lappegård, T. and M. Rønsen, 2005. The multifaceted impact of education on entry into motherhood. European Journal of Population 21: 31-49.

Lesthaeghe, R. and G. Moors, 2000. Recent trends in fertility and household formation in the industrialized world. Review of Population and Social Policy 9: 121-170.

Liefbroer, A. C. and M. Corijn, 1999. Who, what, where and when? Specifying the impact of educational attainment and labour force participation on family formation. European Journal of Population 15: 45-75.

Marini, M. M., 1984. Women's educational attainment and the timing of entry into parenthood. American Sociological Review 49(4): 491-511.

MLSA. 2005. Národní koncepce rodinné politiky [National concept of family policy]. Ministry of Labour and Social Affairs of the Czech Republic, Prague.

Možný, I., 1987. "K některým novým jevům v kulturně legitimních vzorcích rodinných startů" [On some new phenomena in culturally legitimate patterns of starting families]. Demografie 29(2): $114-123$

Nešporová, O., 2005. Harmonizace rodiny a zaměstnání. Rodiny s otci na rodičovské dovolené. VÚPSV, Praha.

OECD, 2006. Education at a Glance 2006. OECD.

Oppenheimer, V. K., 2003. Cohabiting and marriage during young men's career-development process. Demography 40(1): 127-149.

Park, C. B., 1976. Lifetime probability of additional births by age and parity for American women, 1935-1968: A new measurement of period fertility. Demography 13(1): 1-17.

Pavlík, Z. and Kučera, M. (eds), 2001. Populační vývoj České republiky 2000. [Population Development in the Czech Republic 2000]. Charles University, Prague.

Polášek, V., 2005. Svobodná matka - a co je potom? [Single mothers - and what follows then?] Demografie 47(4): 287-292.

Poppová, M., 2004. Regionální rozdíly ve vývoji úrovně plodnosti v období 1988-1998 v České republice, Mad'arsku a Polsku. Demografie 46(4): 264-275.

Rabušic, L., 2001. "Value change and demographic behaviour in the Czech Republic". Czech Sociological Review 9(1): 99-122.

Rindfuss, R. R., L. Bumpass and C. St. John, 1980. Education and fertility: Implications for the roles women occupy. American Sociological Review 45(3): 431-447 
Rindfuss, R. R., S. P. Morgan and K. Offutt, 1996. Education and the changing age pattern of American fertility: 1963-1989. Demography 33(3): 277-290.

Rychtaříková, J. 1994. "Les unions informelles en République Tchèque.“ Acta Universitatis Carolinae Geographica Supplementum: 71-85.

Rychtaříková, J., 2000. "Demographic transition or demographic shock in recent population development in the Czech Republic?" Acta Universitatis Carolinae Geographica 1: 89-102.

Rychtaříková, J., 2004. Změny generační plodnosti v České republice se zaměřením na vzdělání žen. Demografie 46(2): 77-90.

Rychtaříková, J., 2006. Je vysoký podíl dětí narozených mimo manželství v ČR projevem westernizace? Zpravodaj České Demografické Společnosti 40: 4-7.

Ryder, N. B., 1965. The measurement of fertility patterns. In.: Sheps, M. C. and J. C. Ridley (eds.) Public Health and Population Change. University of Pittsburgh Press: 287-306.

Sobotka, T., K. Zeman and V. Kantorová, 2003. Demographic shifts in the Czech Republic after 1989: A second demographic transition view. European Journal of Population 19(3): 249277

Soukupová, E., 2006. Jak je výhodné míti manžela. In.: Hamplová, D. (ed.) (2006).

Srb, V., 2006. Vzdělanostní homogamie a heterogamie v manželství v České republice v roce 2001. Demografie 48(4): 289-290.

Stloukal, L., 1997. Changing patterns of extramarital conceptions in the Czech Republic, 1960-1993. Journal of Biosociological Science 29: 471-489.

UZIS, 2006. Činnost kojeneckých ústavů a dětských domovů pro děti do tř̌́ let a dalších zařízení pro děti v roce 2005. [Activity of institutes for infants and homes for children up to 3 years of age and other institution for children in 2005]. Aktuální informace 19.

Vašková, R., 2006. Rozhodovací procesy -náctiletých těhotných dívek vedoucí k volbě časného rodičovství. In.: Hamplová,D., P. Šalamounová and G. Šamanová (eds.). Životní cyklus sociologické a demografické perspektivy. Institute of Sociology of the Academy of Sciences of the Czech Republic, Prague.

Večerník, J., 1999. Inequalities in earnings, incomes, and household wealth. In: J. Večerník and P. Matěju (eds.). Ten Years of Rebuilding Capitalism: Czech Society After 1989. Academia, Prague: $115-136$.

Zeman, K., 2003. Divorce and Marital Dissolution in the Czech Republic and in Austria - The Role of Premarital Cohabitation. Diploma Thesis, Charles University in Prague.

Zeman, K., 2006. Vývoj obyvatelstva České republiky v roce 2005. [Population development in the Czech Republic in 2005]. Demografie 48(3): 153-165. 